(чем в учебниках русского языка для начальных классов) и способствовать решению лексико-словообразовательных задач.

1. Иванов С.В. и др. Русский язык: 2 класс: учебник для учащихся общеобразовательных учреждений: в 2 ч. Ч.2. - М.: Вентана - Граф, 2013.176 с.

\title{
Мешкова И.В.
}

Об отношении современной молодежи к ненормативной лексике

Нижнетагильский государственный сочиально-педагогический институт (филиал) ФГАОУ ВО «Российский государственный профессионально-педагогический университет»

(Россия, Нижний Тагил)

doi: $10.18411 / 1 j-07-2021-140$

\section{Аннотация}

В статье рассматривается проблема равнодушного отношения современной молодежи к широкому использованию ненормативной лексики в речи людей разного возраста. Представлены результаты анкетного опроса студентов педагогического вуза об их отношении к использованию ненормативной лексики. Выявлено, что $66 \%$ относятся с безразличием к употреблению нецензурных выражений друзьями, 27\% сочли возможным поддержать разговор с использованием таких слов.

Ключевые слова: ненормативная лексика, нецензурные выражения, молодежь, речевая культура.

\section{Abstract}

The article discusses the problem of indifference of modern youth to the widespread use of profanity in the speech of people of different ages. The results of a questionnaire survey of students of a pedagogical university about their attitude to the use of profanity are presented. It was revealed that $66 \%$ are indifferent to the use of obscene expressions by friends, $27 \%$ considered it possible to maintain a conversation using such words.

Keywords: profanity, obscene expressions, youth, speech culture.

Обращение к проблеме кризиса культуры устной русской речи, который выражается в повсеместном, часто открытом употреблении ненормативной лексики, обусловлено необходимостью формирования коммуникативной компетентности современного специалиста, осознанного отношения выпускника педагогического вуза к изучению причин использования детьми и взрослыми ненормативной лексики в существующих социокультурных условиях развития российского общества.

Культура речи может рассматриваться как часть общей культуры человека. В Большой российской энциклопедии понятие «культура речи» определяется как «владение нормами литературного языка в его устной и письменной форме, а также умение использовать выразительные средства языка в соответствии с целями и содержанием речи» [6]. Культура речи предполагает не только знание норм литературного языка, его выразительных возможностей и национальных особенностей, но и правильное отношение к тому, что именуется ненормативной лексикой [3, с. 306].

Ненормативная лексика (обсценная лексика) - сегмент бранной лексики различных языков, включающий грубейшие бранные выражения, часто выражающие спонтанную речевую реакцию на неожиданную (обычно неприятную) ситуацию [4].

Выделяют различные функции употребления обсценной лексики:

- повышение эмоциональности речи;

- разрядка психологического напряжения; 
- оскорбление, унижение адресата речи;

- демонстрация раскованности, независимости говорящего;

- демонстрация пренебрежительного отношения к системе запретов и др. [4].

По мнению Н.И. Козлова, ненормативная лексика характерна для людей с выраженным негативизмом и низким уровнем культуры. Часть людей обращается к нецензурным выражениям как к яркому и резкому языковому жесту, который выделяет и подчеркивает сказанное, а иногда и характеризует автора как «смелого» человека, чуждого условностей и ограничений [2]. Несомненно, что считать нормой такое речевое поведение нельзя, оно ведет куничтожению культуры речи, где людям придется жить в условиях «языковой грязи».

Целью проведенного исследования являлось выявление отношения студенческой молодежи к использованию ненормативной лексики среди молодежи. В анкетном опросе приняли участие студенты 1-4 курсов очной формы обучения Нижнетагильского государственного социально-педагогического института в количестве 70 человек, из них 20 юношей (29\%) и 50 девушек (71\%) в возрасте от 17 до 23 лет.

На вопрос «Что такое нецензурная брань в вашем понимании?» большинство студентов (57\%) выбрали вариант ответа — «простое ругательство». Некоторые студенты характеризуют нецензурные выражения как одно из средств выражения эмоций: «это яркое выражение своих эмоций, когда не можешь подобрать цензурные слова». Противоречивость мнений нашла отражение в таких ответах: «это ругательные слова, не обремененные смыслом» и «слова-паразиты, имеющие большое количество смысловой нагрузки». В этих ответах проявляется индивидуальный смысл, который вкладывают молодые люди в понятие «ненормативная лексика».

Степень распространенности использования нецензурных выражений диагностировалась вопросом «Часто ли Вам приходится слышать нецензурные слова?». Около двух третей опрошенных (74\%) ответили, что им часто приходится слышать нецензурные слова. Такой ответ большинства опрошенных студентов можно рассматривать как признак низкого уровня коммуникативной культуры в обществе. Было выявлено, что $16 \%$ из числа опрошенных студентов не задумывались о том, насколько часто им приходится слышать нецензурные слова. Этот факт может свидетельствовать о некритическом отношении студентов к чистоте и культуре своей речи и речи окружающих их людей.

Большая часть опрошенных (69\%) ответили, что ненормативную лексику они слышат «везде» - в общественных местах, на улице, в том числе в Интернете. По 43\% опрошенных ответили, что ненормативную лексику слышат «в общественном транспорте», «в местах отдыха», «в институте». Обращает на себя внимание ответ 43\% опрошенных, которые слышат ненормативную лексику «в педагогическом институте». Выявленный эмпирический факт требует дополнительного внимания со стороны педагогов, осуществляющих профессиональную подготовку будущих специалистов в области обучения и воспитания подрастающего поколения. Культура речи составляет основу не только профессиональной коммуникативной компетентности современного педагога, но и входит в структуру профессиональной Я-концепции. Использование между студентами ненормативной лексики не способствует формированию профессионально компетентных педагогов.

По мнению студентов, чаще используют в своей речи ненормативную лексику: подростки - 66\%, мужчины - 47\%, сверстники (юноши и девушки) - 39\%. Также студенты отмечали, что ненормативную лексику они слышали от детей младшего школьного возраста, женщин, пожилых людей. 
При этом в качестве примера речевой культуры студенты называют педагогов $43 \%$, родителей - 37\%, известных, публичных людей - 33\%, друзей - $10 \%$.

Отвечая на вопрос «Как часто вы сами употребляете нецензурные слова», большинство респондентов выбрали ответ - «иногда» (74\%), 15 человек из 70 опрошенных $(21 \%)$ признали, что употребляют нецензурные выражения «часто». Лишь трое участников опроса (4\%) ответили, что никогда не употребляют нецензурные выражения. Можно сказать, что студентам, употребляющим в своей речи нецензурные выражения «часто» (21\%), труднее всего будет подготовиться к выполнению профессиональной педагогической деятельности, к успешному решению коммуникативных задач в общении со всеми участниками образовательного процесса.

Ответы, характеризующие отношение студентов к употреблению нецензурных слов друзьями, распределились так:

- отношусь с безразличием - $66 \%$,

- могу поддержать разговор в таком формате - $27 \%$.

- прошу при мне не употреблять подобных выражений - $11 \%$,

- возмущаюсь про себя и стараюсь не слушать - по 3 человека (4\%).

Равнодушных оказалось больше всего (66\%), способных поддержать разговор с использованием нецензурных выражений - около трети опрошенных (27\%). С одной стороны, этот факт можно объяснить возрастными и социальными особенностями языковой культуры студентов педагогического вуза, хотя в большей степени такие особенности характерны для подросткового возраста. С другой стороны, этот факт свидетельствует о низком уровне социальной зрелости молодых людей. Всего $11 \%$ готовы проявить активную нетерпимую позицию в ситуации использования ненормативной лексики в их присутствии.

Среди причин использования ненормативной лексики среди молодежи студенты назвали такие:

— влияние общества, ближайшего окружения - $81 \%$,

- влияние социальных сетей (определенного контента), мода - 64\%,

- недостатки воспитания в семье - $34 \%$,

- возрастные особенности - $31 \%$,

- образ «героя», использующего ненормативную лексику - $30 \%$.

Можно отметить, что большинство студентов, принимавших участие в опросе, называют социальные причины использования ненормативной лексики среди молодежи, что формирует их терпимое отношение к использованию ненормативной лексики. Об этом свидетельствуют и результаты исследований других авторов $[1 ; 3 ; 5]$.

Таким образом, результаты проведенного исследования позволяют сделать следующие выводы:

1. Социокультурная среда современного российского общества характеризуется широким использованием нецензурных выражений. Около двух третей опрошенных (74\%) ответили, что им часто приходится слышать нецензурные слова, а 69\% отметили, что ненормативную лексику они слышат «везде» — в общественных местах, на улице, в Интернете и т. д.

2. Среди основных причин использования среди молодежи нецензурной лексики студенты назвали «влияние общества, ближайшего окружения» (81\%), «влияние социальных сетей (определенного контента), мода» (64\%) и др. социальные причины.

3. Большая часть студентов, принимавших участие в анкетном опросе (66\%), равнодушно относится к использованию ненормативной лексики 
в кругу друзей, $27 \%$ сочли возможным поддержать разговор с использованием таких слов.

$* * *$

1. Ищенко Д. С. Ненормативная лексика как девиация в молодежной среде // Современный взгляд на будущее науки: сб. ст. Междунар. науч.-практ. конф. (Томск, 25 мая 2016 г.). Уфа, 2016. С. 201203.

2. Козлов Н.И. Мат и ненормативная лексика: зачем? [Электронный ресурс] // Психологос. Энциклопедия практической психологии. URL: https://www.psychologos.ru/articles/view/mat-inenormativnaya-leksika-dvoe-zn--zachem-vop-zn- (дата обращения: 04.07.21).

3. Москвина Н.Р. Ненормативная лексика как социокультурная проблема современной молодежи // Социокультурное развитие большого Урала: тренды, проблемы, перспективы: материалы юбил. Bсерос. науч.-практ. конф. «ХХ Уральские социологические чтения» (Екатеринбург, 27-28 февр. 2015 г.) / под общ. ред. Ю. Р. Вишневского. Екатеринбург: УрФУ, 2015. С. 306-310. URL: https://elar.urfu.ru/bitstream/10995/31919/1/srbu_2015_61.pdf

4. Ненормативная лексика [Электронный ресурс] // academic.ru Словари и энциклопедии на Академике. URL: https://dic.academic.ru/dic.nsf/ruwiki/20443

5. Пацыба В.И. Взаимосвязь склонности к ненормативному речевому поведению и ценностных ориентаций личности: автореф. дис. ... канд. психол. наук. Саратов, 2009. 20 с.

6. Шмелёв А.Д. Культура речи // Большая российская энциклопедия. Электронная версия (2016). URL: https://bigenc.ru/linguistics/text/2121027 (дата обращения: 02.07.2021).

\section{Мироненко В.В., Гулякин Д.В. \\ Объектная и социокультурная обусловленность научного познания и его динамики}

Кубанский государственный технологический университет (Россия, Краснодар)

doi: $10.18411 / \mathrm{lj}-07-2021-141$

\section{Аннотация}

Рассмотрена социокультурная обусловленность научного познания, его динамика, основные свойства. Рассмотрен метод научного познания в плане детерминации, а также значимость научного познания.

Ключевые слова: Социокультурная обусловленность познания, динамика научного познания, гуманитаризация и аксиоматизация знания, методология.

\section{Abstract}

The socio-cultural conditionality of scientific knowledge, its dynamics, basic properties are considered. The method of scientific knowledge in terms of determination is considered, as well as the significance of scientific knowledge.

Keywords: Sociocultural conditioning of cognition, dynamics of scientific knowledge, humanization and axiomatization of knowledge, methodology.

Научное познание - особый вид познавательной деятельности, направленный на выработку объективных, системно-организованных и обоснованных знаний о природе, человеке и обществе.

Особенности научного познания:

Особые (научные) методы познания окружающего мира.

Стремление к объективности и достоверности: изучить мир таким, какой он есть, независимо от человека.

Подверженность рациональной критике, проверяемость.

Рациональность, связанная с непротиворечивостью, доказательностью и системностью. 